\title{
EXINE STRUCTURE IN CBCROPIA L. (MORACEAE) POLLEN GRAINS
}

Ortrud Monika Barth ${ }^{1}$

\section{ABSTRACT}

Species of the genus Cecropia have very small pollen grains. The exine stratification and surface ornamentation are here elucidated by means of electron microscope observations. The ten species studied may be divided into two groups according to the distribution of spinules over the pollen grain surfaces: one group with uniform distribution and the other with spinules only at equatorial regions so that the polar areas are nearly smooth. From the surface inward, the exine presents supratectal spinules; a well formed tectum traversed by very small channels; short and fine bacula; a discontinuous nexine 1 and a continuous nexine 2 , which is thicker around the pores. With respect to the differentiation of the exine structure, Cecropia exhibits a degree of evolution within the Moraceae family, which argues against any approximation of this genus to the Urticaceae family.

\section{RESUMO}

Devido ao pequeno tamanho dos grãos de pólen de espécies do gênero Cecropia, é elucidada no presente trabalho a estratificação da exina e a ornamentação das superfícies por meio de observações em microscopia eletrônica. As 10 espécies estudadas podem ser separadas em dois grupos segundo a distribuição dos espículos na superfície dos grãos de pólen: distribuição uniforme com espículos acumulados na faixa equatorial, deixando as áreas polares praticamente lisas. A exina é estruturada de fora para dentro por espículos supratectais, de um teto bem desenvolvido atravessado por diminutos canalículos, báculos curtos e delgados, uma nexina 1 descontínua e uma nexina 2 contínua, espessada em volta dos poros. De acordo com estas diferenciações da estrutura da exina, o gênero Cecropia apresenta dentro da família Moraceae um certo grau de evolução que não apoia a sua aproximação à família Urticaceae.

\section{INTRODUCTION}

Numerous species of Cecropia (Moraceae) occur within tropical regions, mainly along river margins. In the Atlantic forest of eastern Brazil, they are considered as indicative of secondary forests. Their pollen grains are wind dispersed and occur frequently in air sediments (BARTH et al., 1975), honey sediments (BARTH, 1970) and soil sediments (ABSY, 1979). The more frequent common names are: "embaúbas, imbaúbas or cecrópias".

The pollen grains of Cecropia present a special morphology that distinguishes them from other genera. The details of surface ornamentation and exine stratification can not be well defined by light microscopy (LM) because of the small size of the pollen grains. Scanning electron microscope (SEM) observations were made by BARTH (1974, 1984), thereby detailing and extending the published record of LM pollen characteristics (ERDTMAN, 1952; BARTH, 1976;

\footnotetext{
1Instituto Oswaldo Cruz, C.P. 926, 20010 - Rio de Janeiro - Brasil

Bolsista do Conselho Nacional de Desenvolvimento Científico e Tecnológico.
} 
RAMOS - ZAMORA, 1977).

The exine structure, on the other hand, is still not well elucidated, MARTINEZ-HERNANDEZ et al. (1979) present a cross section through the C. obtusifolia exine, but several fundamental questions as to texture remain unsolved for this and other species. The present paper answers some of these questions.

\section{MATERIAL AND METHODS}

Pollen grains samples were obtained from the following herbaria: Herbário "Alberto Castellanos", FEEMA, Rio de Janeiro (GUA); Herbário "Barbosa Rodrigues", Itajaí, Santa Catarina (HBR); Herbário do Museu Paraense Emílio Goeldi, Belém, Pará (MG); Herbário do Jardim Botânico, Rio de Janeiro (RB). Specimens examined were:

Cecropia adenopus Mart. ex Miq.; Irwin, Grear, Souza \& Santos 14.415 (MG)

C. catharinensis Cuatrecasas; Hatschbach 5.103 (HBR); Carauta 620 (GUA)

C. glazioui Snethlage; Klein \& Souza 7.329 (HBR); Liene, Pereira 3.944, Sucre \& Duarte (RB)

C. hololeuca Miquel; Angeli 350 (MG)

C. Iyratiloba Miquel; Carauta 225 (MG)

C. obtusa Trécul; Reitz C-467 (HBR)

C. pachystachya Trécul; Brito \& Vinha 228 (MG)

C. palmata Willdenow; Carauta 554 (GUA); Carauta 969A (GUA)

C. sciadophylla Mart.; Egler 439 (MG)

C. surinamensis Miquel; P. Cavalcante 1.392 (MG)

Fragments of male inflorescences were ground, acetolysed and embedded in glycerine jelly for LM observations. Samples for SEM observations were transfered from water to $70 \%$ ethanol after acetolysis, dripped into microscope stubs and left overnight at $37^{\circ} \mathrm{C}$ to dry; they were then sputtered with a $20 \mathrm{~mm}$-thick layer of gold and observed in a JEOL 25-SII scanning electron microscope at $12,5 \mathrm{kV}$. For ultrathin sections, the acetolysed pollen grains were placed in $2 \%$ agarose, dehydrated in successively higher concentration of acetone, and small pieces embedded in araldite; sections were cut with a diamond knife, stained with uranyl acetate and lead citrate, and observed in a ZEISS EM-10B transmission electron microscope (TEM).

\section{RESULTS}

Cecropia pollen grains are unmistakably distinct from other pollen grains or the basis of their form and small size. The smallest grains among the 10 acetolysed species studied here belong to $C$. hololeuca $(12 \times 8 \mu \mathrm{m})$ and the largest to $C$. palmata $(15,5 \times 9 \mu \mathrm{m})$ (Table 1). The pollen grains are bilaterally symmetrical, elongate along the polar axis, with two small equatorial pori located opposite each other, each at the center of an annulus ( $=$ thickening of the nexine). In LM observations, the surfaces are smooth (Figs. 1-3, 10, 11), but at magnifications above 1000x, fine granulations are detectable, specially in the equatorial region between the aperture areas.

SEM observations confirm these characteristics. The surface granulations or spinules are indeed more numerous in the equatorial areas (Figs. 4, 5), whereas polar areas may remain smooth (Figs. 12, 13). 


\begin{tabular}{|c|c|c|c|c|c|c|}
\hline \multirow{3}{*}{ Species } & \multicolumn{5}{|c|}{ Measurements $(\mu \mathrm{m})$} & \multirow{3}{*}{$\begin{array}{l}\text { Distribution of } \\
\text { supratectal spinules } \\
\text { general }\end{array}$} \\
\hline & \multicolumn{3}{|c|}{ Polar axis } & \multicolumn{2}{|c|}{$\begin{array}{c}\text { Major equatorial } \\
\text { axis }\end{array}$} & \\
\hline & 15 & $(13$ & $-17,5)$ & 10 & $\left(\begin{array}{ll}8 & -11\end{array}\right)$ & \\
\hline C.catharinensis & 13,5 & & & 9 , & & general \\
\hline C.glazioui & 12,5 & & & 8 , & & equatorial \\
\hline C.hololeuca & 12 & $(11$ & $-13)$ & 8 & $(7,5-9)$ & equatorial \\
\hline C.lyratiloba & 15 & $(13$ & $-16)$ & 10 & $(9.5-11,5)$ & general \\
\hline C.obtusa & $15, c$ & & & 9 , & & equatorial \\
\hline C.pachystachya & 12,5 & $(11$ & $-13,5)$ & 9 & $(8,5-10)$ & general \\
\hline C.palmata & 15,5 & $(14$ & $-16,5)$ & 9 & $\left(\begin{array}{ll}8 & -10\end{array}\right)$ & equatorial \\
\hline C.sciadophylla & 11 & $(10$ & $(-12)$ & 7 & $(6,5-8)$ & equatorial \\
\hline C.surinamensis & 14,5 & $(13$ & $-15,5)$ & 10 & $\left(\begin{array}{ll}10 & -10,5\end{array}\right)$ & general \\
\hline
\end{tabular}

Table 1 - Average grain dimensions and spinule distribution in Cecropia pollen. Size ranges are given in parentheses.

Considering these observations, the studied species of Cecropia may be divided into two groups:

Group A: Species with supratectal spinules over the whole surface, occasionally less numerous at the poles:

C. adenopus, C. catharinensis, C. lyratiloba, C. pachystachya and C. surinamensis.

Group B: Species with supratectal spinules only in equatorial areas; polar areas smooth: $C$. glazioui, C. hololeuca, C. obtusa, C. palmata and C. sciadophylla.

Numerous spinules with large bases and short pointed apices distributed over the entire surface of the grain are characteristic of C. catharinensis (Figs. 4,5) and C. surinamensis pollen. Very small spinules occuring only in equatorial regions are typical of C. palmata (Figs. 12, 13); spinules with slightly larger bases occur in C. glazioui, C. obtusa and $C$. sciadophylla.

Exine stratification may be examined in ultrathin sections (Figs. 6, 14). The tectum is relatively thick (Fig. 7) and texturally homogenous, with compact supratectal spinules, which may be limited to the equatorial areas in some species (Fig. 14). Small channels traversing the tectum may be observed at very high magnifications (above $20000 \mathrm{X}$ ) (Fig. 7) connecting the interior of the grain to the surface; around the spinules their diameters are larger (Textfig. 1). Below the tectum, the next layer of the exine is formed by very short and narrow bacula, sometimes branched, numerous and winding, so that they may appear like small granula in cross section. The bacula may be joined at their bases to form discontinuous plates parallel to the surface that correspond to nexine 1. At this point, partial separation frequently occurs between sexine and nexine in acetolysed pollen grains (Figs. 8, 15). Nexine 2 in the polar regions of grains is two or three times thinner than the tectum; however at 
the annuli it is thicker. The inner side of the pori presents numerous short filaments of nexine 2; their internal diameters are larger than the outer aperture at the tectum (Figs. 8, $9,16)$.

Ubisch bodies or orbicules (Fig. 15) present an electron-translucent core and an irregularly structured surface.

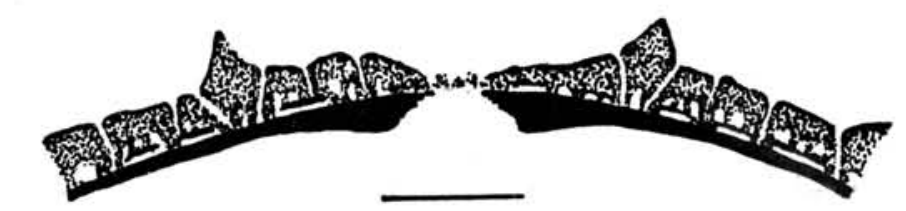

Fig. 1 - Schematic Cecropia exine structure (bar = $1 \mu \mathrm{m})$.

\section{DISCUSSION}

Cecropia pollen grains are commonly detected in honey samples, and as these grains are not acetolysed, they maintain their cytoplasmic contents. The polar and equatorial diameters are $8,5 \times 7 \mu \mathrm{m}$, respectively, but after acetolysis, their dimensions increase to ca. $14 \times 9 \mu \mathrm{m}$ (ERDTMAN, 1952; BARTH et al., 1975; BARTH, 1976), and they frequently do not maintain their original form due to the fragility of nexine 2.

The pollen grains morphology of Cecropia differs considerably frnm that of other genera of Moracea (BARTH, 1984). Uniformly distributed supratectal spinules are frequent in several genera (RAMOS-ZAMORA, 1977; BARTH, 1984), but their concentration in the equatorial region of the pollen grains is typical for Cecropia (BARTH, 1974).

The tectum is not imperforate as asserted by MARTINEZ-HERNANNDEZ et al. (1979) for ultrathin sections of $C$. obtusifolia Bertol. Detection of the very small channels inside the tectum (Figs. 7, 16) depends upon the thickness of the section and the resolution of the electron microscope. These same authors also affirm that nexine 2 is lacking: this may be a problem of nexine structure interpretation, as the only illustration presented is not sufficiently clear. Nexine 2 is present in all specimes examined in the present study but is less electron dense than the tectum. The detachment between bacula and nexine in acetolysed preparations may partially explain this fact (Figs. 8, 15). Similar detachments between the bacula layer and nexine 1 also occur in the genus Dorstenia at aperture aspides and interapertural "bleb" formation (BARTH, 1986).

The supratectal spinules have a relatively broad base and a short pointed apex, so that in LM observations they appear as small granula.

Short and thin bacula, sometimes appearing like granula, and a discontinuous nexine 1 may be interpreted as signs of primitivism in the exine structure of Cecropia pollen grains. The thickening of nexine 2 around the apertures, on the other hand, represents a more advanced degree of evolution.

Cecropia and Dorstenia are genera that occupy distinct positions within subfamilies of Moraceae (CORNER, 1962; MELCHIOR, 1964; HUTCHINSON, 1967). Comparisions between their pollen grain morphology (BARTH, 1986) reveal common characteristics, such as the granulate texture of bacula layers and irregular distribution of spinules on their surfaces (absent over the aspides in Dorstenia brasiliensis and in the polar areas of some Cecropia species). A high number of apertures in Dorstenia pollen grains is considered an advanced character, as is the increase in thickness of the nexine 2 or endexine around the two apertures in Cecropia; this places the latter genus in a distinct situation in relation to other genera of the 
subfamily Moroideae which not present this character (BARTH, 1976).

Some authors (CORNER, 1962; HAMILTON, 1976) suggest transfering the genus Cecropia to the Urticaceae family. Pollen morphology does not support this suggestion. In accordance with available palynological data, the pollen grains of the subfamily Moroidaceae (BARTH, 1976) are more closely related to the Urticaceae (HAMILTON, 1976) than is Cecropia of the Conocephaloideae subfamily.

\section{ACKNOWLEDGEMENTS}

I am grateful to the staff of the Laboratory of Electron Microscopy, Biophysical Institute, Federal University of Rio de Janeiro, for the use of their sputtering and scanning electron microscope equipment, to Ms. Maria da Penha R. da Costa for all photographic reproductions and to $\mathrm{Dr}$. T. R. Fairchild for manuscript review.

\section{REFERENCES CITED}

ABSY, M.L. (1979) A Palynological Study of Holocene Sediments in the Amazon Basin. Thesis. University of Amsterdam. 86p.

BARTH, 0.M. (1970) Análise microscópica de algumas amostras de mel 3. Pólen isolado. Anais da Academia Brasileira de Ciências, 42(4):747-772.

BARTH, O.M. (1974) O pólen de algumas espécies de Cecropia (Moraceae). Leandra (UFRJ) IIIIV(4-5): $115-118$.

BARTH, O.M. (1976) Catálogo sistemático dos pólens das plantas arbóreas do Brasil meridional. XXIII - Moraceae. Memórias do Instituto Oswaldo Cruz, 74(3-4):295-309.

BARTH, O.M. (1984) Surface morphology of Brazilian Moraceae pollen grains. Boletim IG-USP. Publicação Especial, 15:142-149.

BARTH, O.M. (1986) Pollen grain morphology of some Brazilian species of Dorstenia L. (Moraceae). Boletim IG-USP. Série Científica, 17:121-129.

BARTH, O.M.; MACIEIRA, E.G.; CORTE-REAL, S. (1975) Morfologia do pólen anemófilo e alergizante no Brasil. I. Casuarinaceae, Salicaceae, Moraceae, Ulmaceae e Urticaceae. Memórias do Instituto Oswaldo Cruz, 73(3):141-152.

CORNER, E.J.H. (1962) The classification of Moraceae. Gard. Bull. Singapore, 19(2):187-252.

MELCHIOR, H. (1964) A Engler's Syllabus der Pflnzenfamilien. II. Gebrueder Borntraeger, Berlin-Nikolassee. 666p.

ERDTMAN, G. (1952) Pollen Morphology and Plant Taxonomy. Angiosperms. Waltham, Mass. Chronica Botanica. 530p.

HAMILTON, A.C. (1976) Identification of east African Urticales pollen. Pollen et Spores, $18(1): 27-66$. 
HUTCHINSON, J. (1967) The Genera of Flowering Plants. (Angiospermae). Vol. II, Dicotyledons. Claredon Press, Oxford. 659p.

MARTINEZ-HERNANDEZ, E.; VARGAS-OLVERA, M.; LUDLOW-WIECHERS, B. (1979) Ultraestrutura de la exina en granos de pólen en Angiospermas. Biotica, 4(1):33-48.

RAMOS-ZAMORA, D. (1977) Morfologia de los granos de pólen de la familia Moraceae en Mexico. Boletim Sociedad Botanica de Mexico, 36:71-93.

Plate I

Pollen grains of Group A.

Figs. 1-2: Cecropia surinamensis: equatorial views, $L M($ bar $=5 \mu \mathrm{m})$.

Figs. 3-9: Cecropia catharinensis.

Fig. 3: Equatorial views, LM $($ bar $=5 \mu \mathrm{m})$.

Fig. 4: Equatorial view, thick spinules at mesoporus and over the entire grain, SEM (bar = $2 \mu \mathrm{m})$.

Fig. 5: Equatorial view with porus at the right, SEM (bar $=2 \mu \mathrm{m}$ ).

Fig. 6: Equatorial view of thin section with two aperture areas, one on each side, TEM (bar $=2 \mu \mathrm{m}$ ).

Fig. 7: Thin channel in the tectum (arrow) TEM (bar $=0,5 \mu \mathrm{m}$ ).

Fig. 8: Bacula detachment from nexine (at right), and cross section of aperture area (top), TEM $($ bar $=2 \mu \mathrm{m})$.

Fig. 9: Cross section of internal part of a porus with thickned nexine 2; arrow = channel, TEM (bar $=0,5 \mu \mathrm{m})$.

Abbreviations: $\quad$ LM $=$ light micrograph; $\quad$ SEM $=$ scanning electron micrograph; TEM = transmission electron micrograph. 
Bol. IG-USP, Publ.Esp., 7:205-213, 1989
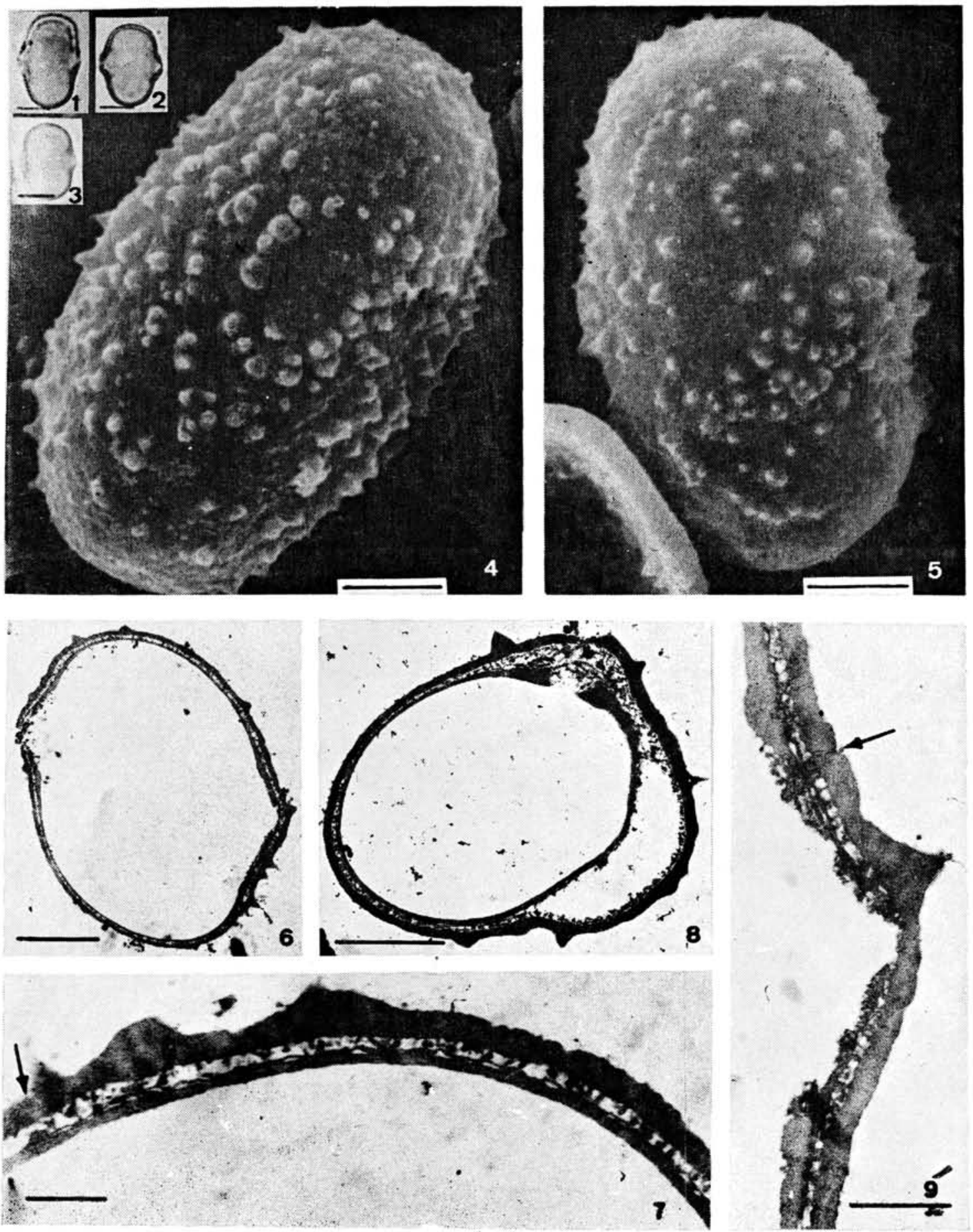


\section{Plate II}

Pollen grains of Group B.

Figs. 10-13: Cecropia palmata.

Fig. 10: Equatorial views, LM (bar $=5 \mu \mathrm{m})$.

Fig. 11: Nexine 2 detachment at the center of the grain (as a dark line), LM (bar $=5 \mu \mathrm{m}$ ).

Fig. 12: Equatorial view, mesoporus with spinules, smooth polar areas, SEM (bar $=2 \mu \mathrm{m})$.

Fig. 13: Equatorial view, porus, $\operatorname{SEM}($ bar $=2 \mu \mathrm{m})$.

Fig. 14-16: Cecropia glazioui.

Fig. 14: Thin sectin in equatorial view with polar nexine 2 detachment, TEM (bar $=1 \mu \mathrm{m}$ ). Fig. 15: Oblique section with several nexine detachments and Ubisch bodies (arrows), TEM (bar $=2 \mu \mathrm{m})$.

Fig. 16: Longitudinal section of an aperture area with nexine 2 thickenings around porus, lamellation of nexine at the aperture, granular bacula stratum and a fine channel in the tectum (arrow), TEM (bar $=0,5 \mu \mathrm{m}$ ).

Abbreviations as in Plate I. 
Bol. IG-USP, Publ.Esp., 7:205-213, 1989
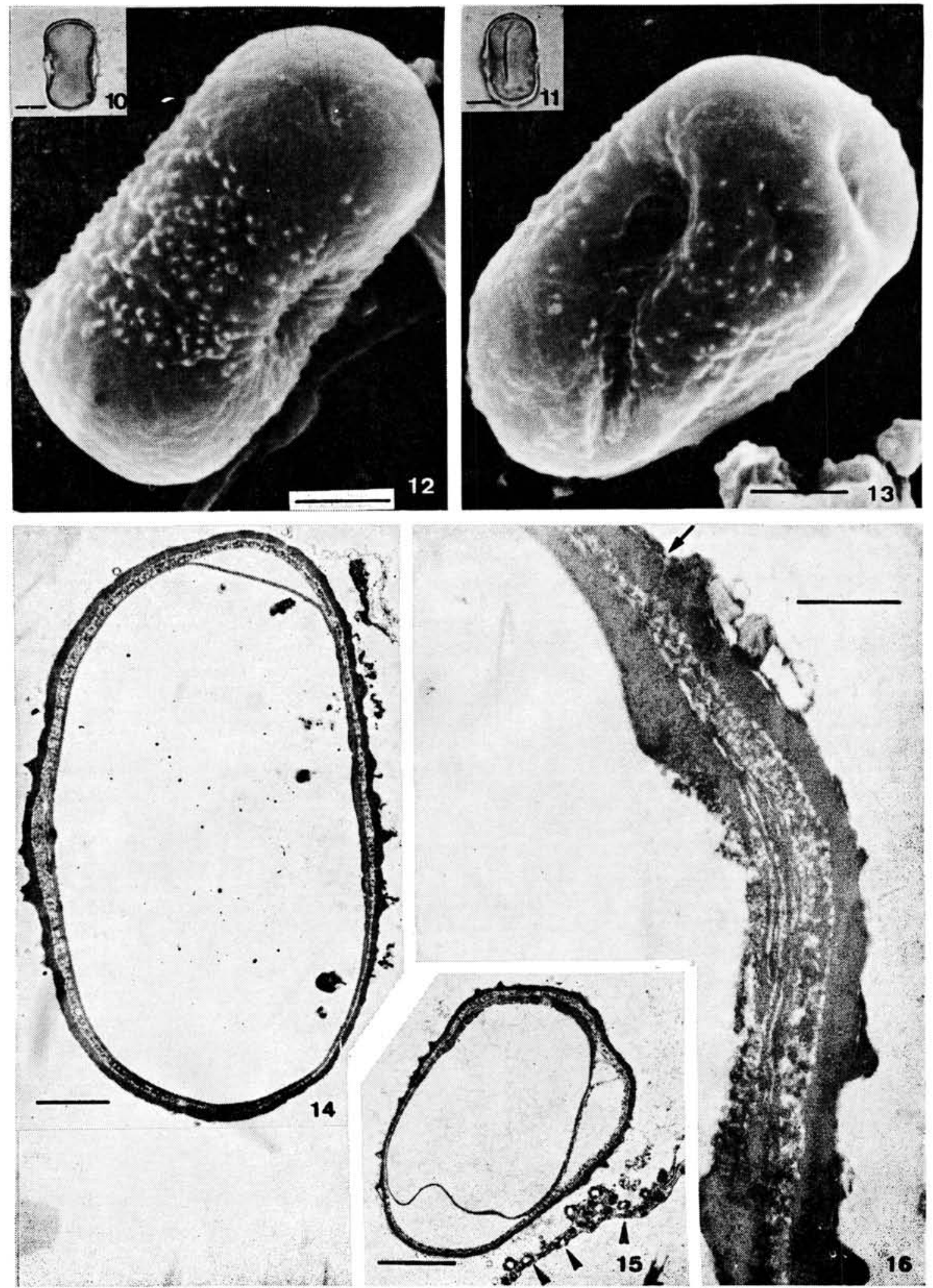